\title{
PENGARUH SENAM OTAK TERHADAP PENINGKATAN SHORT TERM MEMORY PADA LANSIA
}

\author{
Elok Triestuning ${ }^{1}$ \\ ${ }^{1}$ Akademi Keperawatan Kerta Cendekia Sidoarjo \\ *Correspondence: \\ Elok Triestuning \\ Email: deaelok@gmail.com
}

\begin{abstract}
Tahap akhir tumbuh kembang manusia adalah lansia. Banyak perubahan yang terjadi pada lansia. Perubahan mental yang terjadi berupa penurunan intelektualitas yang meliputi persepsi, kemampuan kognitif, memori dan belajar yang menyebabkan mereka sulit untuk dipahami dan berinteraksi. Fakta yang terjadi banyak individu mengalami gangguan memori setelah usia 45 tahun ke atas. Namun kemampuan memori dapat di pertahankan dan di tingkatkan melalui latihan memori jangka pendek. latihan atau teknik yang tepat dilakukan oleh lansia yaitu berupa senam otak yang bertujuan meningkatkan fokus dan bagaimana bisa terus mengaktifkan fungsi otak agar tidak diam yang akhirnya bisa menjadi lemah. Dari beberapa penelitian telah membuktikan bahwa ada pengaruh senam otak terhadap peningkatan short term memory pada lansia karena dengan gerakan senam otak dapat merangsang integrasi kerja bagian otak kanan dan kiri untuk menghasilkan koordinasi fungsi otak yang harmonis sehingga dapat meningkatkan kemampuan memori, kemampuan koordinasi
\end{abstract} tubuh, kemampuan motoric halus dan kasar.

Key words: Lansia, Short term memory, senam otak

\section{PENDAHULUAN}

Lansia merupakan tahap akhir tumbuh kembang manusia. Tahap dewasa merupakan tahap tubuh mencapai titik perkembangan yang maksimal dan kemudian mulai menyusut karena semakin berkurangnya jumlah sel-sel yang ada di dalam tubuh. Selain itu tubuh akan mengalami penurunan fungsi secara perlahan, inilah yang disebut dengan proses penuaan (Maryam, dkk, 2008).

Perubahan psikologis yang terjadi yaitu adanya penurunan intelektualitas yang meliputi persepsi, kemampuan kognitif, memori dan belajar pada usia lanjut menyebabkan mereka sulit untuk dipahami dan berinteraksi. Pelupa merupakan keluhan yang sering dikemukakan oleh manula. Keluhan ini dianggap wajar dan biasa oleh masyarakat sekitarnya. Keluhan ini didasarkan atas fakta. Lumbantobing (2006) menyatakan dari penelitian cross-sectional dan longitudinal didapatkan bahwa kebanyakan individu mengalami gangguan memori dan belajar dengan melanjutnya usia terutama setelah usia 70 tahun. Kita mengetahui bahwa beberapa kemampuan mental menurun dengan melanjutnya usia, misalnya memori jangka pendek dan 
kecepatan melakukan tugas-tugas tertentu. Namun ada beberapa upaya yang dapat dilakukan untuk menetralisir keadaan ini antara lain dengan cara meningkatkan konsentrasi, seperti yang diungkapkan Lumbantobing (2006) bahwa kemampuan memori dapat ditingkatkan melalui latihan memori jangka pendek. Latihan-latihan ini berupa teknik untuk meningkatkan fokus dan kemampuan asosiasi. Intinya dalam latihan meningkatkan memori jangka pendek ini bagaimana kita harus terus bisa mengaktifkan fungsi otak agar tidak diam yang akhirnya bisa menjadi lemah. Karena otak yang selalu aktif membuat otak menjadi sehat dan memiliki ingatan jangka pendek yang lebih baik. Latihan atau teknik yang tepat dilakukan oleh lansia adalah senam otak (brain gym).

$\begin{array}{rrr}\text { Etik } & \text { Pratiwi } & (2016), \\ \text { penelitiannya } & \text { telah } & \text { mempraktekkan }\end{array}$ gerakan senam otak pada lansia. Adapun gerakan senam otak yang dipraktekkan dalam penelitiannya adalah Gerakan menyeberangi garis tengah (The Middle Movements) yang terdiri dari Gerakan Silang (Cross Crawl). Gerakan silang dilakukan dengan cara kaki dan tangan digerakkan secara berlawanan. Gerakan ini bermanfaat merangsang bagian otak yang menerima informasi (receptive) dan bagian yang menggunakan informasi (expressive) sehingga memudahkan proses mempelajari hal-hal baru dan meningkatkan daya ingat. Gerakan 8 Tidur (lazy 8s) gerakan ini dilakukan dengan cara meluruskan tubuh menghadap suatu titik yang terletak setinggi posisi mata sebagai titik tengah dari angka 8. Kemudian gerakkan tangan mulai dari titik tengah ke arah kiri atas, melingkar ke kiri bawah, naik ke titik tengah lagi dan terus ke kanan atas berputar ke kanan bawah, kembali ke titik tengah, demikian seterusnya. Mata mengikuti 8 tidur, kepala bergerak sedikit dan leher tetap rileks. Gerakan ini bermanfaat mengaktifkan dan mengintegrasikan mata kanan dan kiri, mengaktifkan kedua belahan otak untuk bekerja sama dengan baik. Gerakan lain yang dilakukan dalam senam otak pada lansia ini adalah gerakan Gajah (The Elephant). Gerakan gajah dilakukan dengan cara berdiri dengan lutut tertekuk senyaman mungkin, kemudian telinga diletakkan diatas bahu, tangan direntangkan lurus kedepan. Kita bisa membayangkan tangan menjadi belalai gajah yang menyatu dengan kepala, dan mata diarahkan melewati jari tangan ke kejauhan sambil melakukan gerakan 8 tidur. Gerakan Putaran Leher (Neck Rolls). Gerakan putaran leher dilakukan dengan cara menundukkan kepala ke depan, bahu dinaikkan dan secara perlahan leher diputar dari satu sisi ke sisi lainnya sambil bernafas dalam. Putaran leher dapat dilakukan dengan mata terbuka atau tertutup. Gerakan ini bermanfaat melepaskan ketegangan, memacu kemampuan penglihatan dengan kedua mata (binokuler), meningkatkan kemampuan berbicara dan berbahasa, memacu kemampuan penglihatan dengan kedua mata (binokuler), mengaktifkan otak untuk: pemusatan, sistem saraf pusat lebih rileks. Gerakan Pernafasan Perut (Belly Breathing). Gerakan ini dilakukan oleh lansia dengan cara meletakkan tangan di perut kenudian menghembuskan nafas pendekpendek melalui bibir yang diruncingkan, mengambil nafas dalam, dan menghembuskannya pelan-pelan. Pada waktu mengambil nafas perut ikut mengembung dan pada waktu menghembuskan nafas perut kembali seperti semula. Gerakan ini bermanfaat mengaktifkan otak untuk: pemusatan 
(centering), sistem saraf pusat lebih relaks, ritme gerakan tulang kepala; kemampuan akademik yaitu membaca; mengalirkan oksigen ke otak sehingga meningkatkan fungsi otak secara lebih khusus. Gerakan Membayangkan huruf X bermanfaat untuk mengaktifkan otak untuk penglihatan dengan kedua mata secara bergantian, koordinasi seluruh tubuh, dan penglihatan terpusat. Gerakan selanjutnya adalah Gerakan Meregangkan Otot (Lengthening Activities) yang terdiri dari gerakan burung -hantu (The $O w l$ ), Gerakan ini dilakukan dengan cara memijat satu bahu untuk merilekskan otot leher yang tegang dengan tangan yang berlawanan, gerakkan kepala ke kiri dan ke kanan, keluarkan nafas pada setiap putaran kepala. Pada setiap hembusan diharapkan kepala lebih jauh digerakkan ke posisi pendengaran kiri dan kanan. Gerakan ini bermanfaat melepaskan ketegangan tengkuk dan bahu, meningkatkan kemampuan fokus, perhatian dan ingatan. Mengaktifkan otak untuk ingatan jangka pendek dan panjang, bicara dalam hati dan kemampuan berpikir, integrasi penglihatan dan pendengaran. Gerakan Mengaktifkan Tangan (Arm Activation). Gerakan ini dilakukan dengan cara meluruskan satu tangan ke atas ke samping telinga, kepala tetap rileks. Gerakan dilakukan pada empat posisi: menjauhi kepala, ke depan, ke belakang, dan ke arah telinga. Tangan yang lain menahan dorongan tersebut sambil menghembuskan nafas saat menggerakkan tangan. Gerakan Lambaian Kaki (The Footflex). Gerakan lambaikan kaki dilakukan dengan cara duduk dengan pergelangan kaki diletakkan pada lutut yang lain, kemudian tempelkan ujung jari pada awal dan akhir daerah otot betis, cengkeram tempat-tempat yang terasa sakit di pergelangan kaki, betis, dan belakang lutut satu per satu, sambil pelanpelan kaki dilambaikan ke atas dan ke bawah. Gerakan Pompa Betis (The Calf Pump). Gerakan pompa betis dilakukan dengan cara berdiri dan menyanggakan tangannya pada dinding atau sandaran kursi. Salah satu kaki ke belakang dan badan condong ke depan, menekukan lutut kaki yang di depan. Kaki belakang dan punggung membentuk satu garis lurus. Hembuskan nafas saat menekankan tumit ke lantai, angkat waktu menarik nafas. Gerakan Pasang Kuda-Kuda (Grounder). Gerakan pasang kuda-kuda dilakukan dengan cara kaki dibuka dengan jarak sedikit lebih lebar, arahkan kaki kanan ke kanan dan kaki kiri tetap lurus ke depan, tekuk lutut kanan sambil membuang nafas lalu mengambil nafas sewaktu kaki kanan diluruskan kembali.

Latihan senam otak pada lansia ini diperkuat oleh Penelitian psikologi Michael Marsiske's dalam American Psychological Association (2006) yang menuliskan, dengan adanya penurunan memori mengakibatkan permasalahan yang dialami oleh lansia. Namun hal itu bisa dicegah dengan melatih lansia untuk terus bergerak dan beraktifitas. Azwar Agoes, Dkk (2009) juga mengungkapkan Seseorang dengan usia 65-74 tahun mengalami permasalahan atau kemunduran daya ingat, otak dapat mengalami atrofi layaknya otot oleh sebab itu otak juga memerlukan latihan yang teratur agar tetap sehat dan segar.

\section{TINJAUAN TEORI}

\section{Lansia}

Setiap makhluk hidup akan mengalami proses menua termasuk manusia. Menjadi tua merupakan proses alamiah yang berarti seseorang telah melalui tiga tahap kehidupannya yaitu 
anak, dewasa dan tua. Memasuki usia tua berarti mengalami kemunduran misalnya kemunduran fisik dan proses berfikir (Wahyudi Nugroho, 2008).

WHO dan UU No 13 tahun 1998 tentang kesejahteraan lanjut usia pada bab 1 pasal 1 ayat 2 menyebutkan bahwa umur 60 tahun adalah usia permulaan tua.

Dalam buku ajar geriatric Prof. Dr. R. Boedhi Darmojo dan Dr. H. Hadi Martono (1994) juga mengatakan bahwa menua (menjadi tua) adalah suatu proses menghilangnya secara perlahan kemampuan jaringan untuk memperbaiki diri atau mengganti diri dan mempertahankan struktur dan fungsi normalnya sehingga tidak dapat bertahan terhadap jejas dan memperbaiki kerusakan yang diderita.

$$
\text { Wahyudi Nugroho }
$$

menyebutkan perubahan yang terjadi pada lansia tidak hanya pada perubahan fisik melainkan juga perubahan mental yaitu memori baik memori jangka panjang maupun memori jangka pendek.

\section{Memori}

Memori adalah kemampuan suatu organisme untuk menyimpan dan kemudian mengingat informasi (wikibooks contributors, 2006). Lumbantobing (2006) menyebutkan Ada beberapa cara mengklasifikasikan kenangan, berdasarkan durasi, sifat dan pengambilan informasi. Masih dalam Lumbantobing, bahwa sebuah informasi Perspektif pengolahan ada tiga tahap utama dalam pembentukan dan pengambilan memori yaitu pengkodean (pengolahan dan penggabungan informasi yang diterima), penyimpanan (pembuatan rekaman permanen informasi yang dikodekan), pengambilan/ recall (memanggil kembali informasi yang tersimpan sebagai tanggapan atas beberapa isyarat yang digunakan dalam beberapa proses atau aktivitas).

Proses Memori bermula pada encoding yaitu informasi yang di dapat ditransfer ke dalam memori. Setelah encoding selanjutnya adalah storage yang merupakan proses dimana informasi dipertahankan dalam memori. Penyimpanan informasi ini, berupa: memori deklaratif yaitu memori dari faktafakta dan memori procedural yaitu memori suatu skill dan rutin. Proses yang terakhir adalah retrieval yaitu merupakan proses dimana informasi dipanggil kembali dari memori.

Memori dapat juga dibagi dari segi waktu yaitu yang pertama memori jangka pendek (short term memory) yang mencakup kejadian selama 30 menit terakhir dan beberapa minggu. Kemampuan memori jangka pendek dapat di tes dengan menyuruh penderita mengingat sesuatu, misalnya: kata, nomor atau nama dan menyuruh mengemukakannya kembali setelah beberapa saat. Memori jangka pendek dapat di tes dengan menanyakan pertanyaan: "dimana anda tinggal?"," berapa lama anda disini?", "apakah anda tadi pagi sudah sarapan?", memori ini bisa terganggu pada beberapa keadaan misalnya sindrom amnesia, delirium dan demensia. Kedua yaitu memori jangka panjang mencakup kejadian lebih lama dari beberapa minggu yang lalu. memori jangka panjang dapat di tes melalui pertanyaan berikut: "dimana anda sekolah (SD, SMP, SMA), "siapa nama Kepala Sekolah waktu itu?"

Proses memori pada lansia tidak jauh berbeda dengan memori manusia pada usia dewasa. Namun pada lansia seperti halnya kondisi tubuh yang lain otak pun 
juga mengalami penuaan yang akhirnya mempengaruhi system memori khususnya pada memori jangka pendek. Tokoh psikologi kognitif, seperti Fergus Craik dan Timoty Salthouse dalam American Psychological Association (2017) menjelaskan ada beberapa perubahan khas pada system memori lansia. Ketika menginjak usia 40 tahun ke atas terdapat perubahan kemampuan mengingat sesuatu hal yang baru misalnya nama seseorang yang baru dikenalnya atau hal-hal yang terjadi baru saja dalam satu waktu. Hal ini terjadi karena menyusutnya korteks, sel saraf mengalami atrofi dan menyebabkan penurunan kepekaan koneksi antara neuron (dendrit loss).

\section{Senam Otak pada Lansia}

Senam otak tidak hanya dibutuhkan oleh kaum muda saja, namun juga dibutuhkan oleh lansia. Selain membuat bugar senam lansia juga sebagai terapi untuk memperbaiki memori jangka pendek. Hal ini seperti penelitian yang telah dilakukan oleh Faried Rahman dkk (2016), dalam penelitiannya peneliti menggunakan desain Quasy Experiment Design (eksperimen semu) dengan menggunakan rancangan one group pre-test dan post-test design. Dalam metode pengambilan sampel peneliti menggunakan Purposive Sampling. sedangkkan responden yang digunakan yaitu lansia di Panti Sosial Tresna Werda Nirwana Puri Samarinda sebanyak 20 orang. Dari hasil penelitian didapatkan $\mathrm{P}$ value $<\alpha$ atau $0.000<0.05$ dan nilai $\mathrm{T}$ hitung $=6.866$. Hal ini menunjukkan ada pengaruh yang signifikan antara daya ingat jangka pendek dan stress pada lansia sebelum dan sesudah diberikan senam otak. Dalam penelitian tersebut juga menjelaskan bahwa pelaksanaan senam otak secara teratur dapat membantu lansia mengatasi masalah daya ingat jangka pendek dan stress.

$$
\text { Feni Tri Andani (2016) }
$$

menyarankan senam otak dapat direkomendasikan sebagai penatalaksanaan non farmakologi pada lansia dengan dementia, karena dengan gerakan senam otak dapat merangsang integrasi kerja bagian otak kanan dan kiri untuk menghasilkan koordinasi fungsi otak yang harmonis sehingga dapat meningkatkan kemampuan memori, kemampuan koordinasi tubuh, kemampuan motoric halus dan kasar.

Pada penelitian yang berbeda
mengenai latihan memori untuk meningkatkan memori jangka pendek pada lansia yang dilakukan oleh Guillermo Campoy (2008) yang berjudul "the effect of word length in short-term memory: is rehearsal necessary?", disini peneliti mencoba latihan atau senam otak yang tidak berupa gerakan badan kaki atau tangan melainkan permainan kata panjang. Peneliti ingin mengetahui apakah latihan menggunakan kata panjang lebih efektif daripada latihan dengan menggunakan kata-kata pendek. Di sini peneliti menggunakan tiga percobaan yaitu dengan cara memperkenalkan kata panjang dengan enam fonem tanpa penundaan atau jedah dalam pengucapan, yang kedua kata pendek empat fonem tanpa penundaan atau jedah dan percobaan terakhir kata kata panjang enam fonem namun dengan penundaan atau jedah dan diberikan waktu dalam pengucapannya. Peneliti menggunakan analisis variance (ANOVA). Dari hasil penelitian Guillermo Campoy menyimpulkan bahwa dengan menggunakan kata-kata panjang yang disertai penundaan atau jedah lebih efektif 
dapat meningkatkan memori jangka pendek pada lansia dibandingkan dengan tanpa jedah.

Fachrudin Yusuf (2015) dalam penelitiannya yang menggunakan desain pre-experimental dengan pendekatan teknik static group comparison, mengambil sampel sebanyak 34 lansia dan dibagi dua kelompok yang pertama kelompok control yaitu responden tidak diberikan senam otak sedangkan kelompok kedua adalah kelompok perlakuan yaitu responden diberikan senam otak. Hasil penelitian didapatkan nilai $\mathrm{p}=0.317$ pada kelompok control dan nilai 0.000 pada kelompok perlakuan. Hal ini menunjukkan terdapat pengaruh senam otak terhadap peningkatan daya ingat jangka pendek lansia.

Hal ini sesuai dengan yang dikatakan oleh Azwar, Dkk (2009) bahwa lansia memang sudah mengalami penurunan daya ingat namun masih bisa tetap dipertahankan dengan cara latihanlatihan senam otak antara lain menggunakan permainan Bahasa, gerak aktif dan sering mempergunakannya.

\section{DAFTAR PUSTAKA}

1. Agoes, Azwar, dkk. (2009). Penyakit di Usia Tua. Jakarta: EGC.

2. Deane, A. (2008). Be Brain Fit. Di akses pada tanggal 07 Januari 2018 melalui https://bebrainfit.com/improveshort-term-memory/.

3. Andana, Feni Tri. (2016). Pengaruh Senam Otak (Brain Gym) terhadap Kejadian Demensia pada Lansia di Balai Pelayanan Sosial Tresna Werdha Unit Budi Luhur Kasongan Bantul. Yogyakarta.

4. APA. (2017). Memory Changes In Older Adults. http: //www.apa.org/print-this.aspx.
5. Campoy Guillermo. (2008). The Effect of Word Length In Short Term Memory: Is Rehearsal Necessary. The Quarterly Journal of Experimental Psychology, 61 (5), 724 - 734.

6. Hidayat, F.R., Dwi Atikah Amina (2016). Pengaruh Senam Otak terhadap Daya Ingat Jangka Pendek dan Stres pada Lansia di Panti Sosial Tresna Werdha Nirwana Pari Samarinda. Jurnal Ilmu Kesehatan, Vol 4, No. 2.

7. Lumbantobing. (2006). Kecerdasan Pada Usia Lnjut dan Demensia. Balai Penerbit. Jakarta: Balai Penerbit.

8. Beselt, M. (2013). How To Improve Your Short Term Memory. Diakses pada tanggal 11 Januari 2018 melalui www.improve-memoryskills.com/short-term-memory.html.

9. Nugroho, Wahyudi. (2008). Keperawatan Gerontik dan Geriatrik. Jakarta: EGC.

10. Pratiwi, Etik. (2016). Gambaran Pelaksanaan Senam Otak (Brain Gym) pada Lansia di Panti Werdha Budi Dharma Yogyakarta. Jurnal Keperawatan Notokusumo vol IV, No I, Agustus 2016. ISSN 2338-4514.

11. Wikibooks Contributors ( 2006). Cognitif Psychology and Cognitive Neuroscience.

http://en.wikibooks.org/wiki/cognitivepsychologi-and-cognitiveneuroscience. 17 September 2017.

12. Fachrudin, Y. (2015). Pengaruh Senam Otak terhadap Peningkatan Daya Ingat Jangka Pendek Lansia dengan Permainan Puzzle di Posyandu Lansia Desa Sepande Sidoarjo. www. Ejurnal.com/2015/12/pengaruh-senamotak-terhadap_19.html. 
Cite This Article Triestuning, E. Pengaruh Senam Otak Terhadap Peningkatan Short Term Memory pada Lansia. Nurse and Health: Jurnal Keperawatan 2018; 7(1): $86-92$. 